\title{
KELSEN BEFORE KELSEN - REFLECTIONS ON HANS KELSEN'S DIE STAATSLEHRE DES DANTE ALIGHIERI
}

\author{
Mario Patrono*
}

In this article, I reflect on Hans Kelsen's first work, Die Staatslehre des Dante Alighieri, which was written in 1905 while he was still a student. There is no English translation of Die Staatslehre. These "reflections" based on the Italian edition of the book are dedicated to the honour of a scholar and a gentleman, Gordon Anderson.

\section{AN INTRODUCTION: HANS KELSEN IN CONTEXT.}

In his book Drei Wurzeln der Politik the German political analyst Dolf Sternberger proposed a threefold classification of various conceptions of politics that developed in the West from ancient Greek to modern times, in three groups or, better, three big "families". ${ }^{1}$ The premise of Dolf Sternberger's reasoning was that politics and conflict are one, or rather that politics finds its justification or raison d'être in terms of conflict: politics exists because of the presence of conflict. Thus briefly put, politics means the (different) positions taken by power in relation to conflicts. The "families" identified by Dolf Sternberger are as follows.

\section{A The Authoritarian View}

According to some thinkers, politics consists essentially in stifling conflicts. Sternberger singles out Machiavelli, who defined the role of the Prince precisely as to create order by stifling conflicts, as the forefather of this "family". We should note however that even before Machiavelli, "absolutist" conceptions of politics were current. In Plato's Republic, for example, at a certain point Thrasymacus, during a discussion between Polemarchus and Socrates, ${ }^{2}$ finally unable to restrain himself any longer,

\footnotetext{
* Emeritus Professor of European and Comparative Public Law at "La Sapienza" University of Rome; former director of the Department of Legal Studies at the University of Padua, and member of Higher Council for Judiciary (Consiglio Superiore della Magistratura); and several times visiting professor at the Law Faculty of Victoria University of Wellington.

1 Dolf Sternberger Drei Wurzeln der Politik (Insel Verlag, Frankfurt, 1978).

2 The Republic of Plato (Allan Bloom (translator), Basic Books, New York 1991).
} 
bursts out shouting: what are you taking about, politics is based on the balance of power; the stronger crushes the weaker imposing his law on the latter. After all, in the Peloponnesian War Thucydides has the Athenians, landing on the island of Melos, state that the stronger state imposes its laws on the weaker. It is the law of nature applied to political conflict.

The most important author after Machiavelli to hold the authoritarian view is without doubt Thomas Hobbes. Here a premise is necessary: from 1642 until the Restoration, England was torn apart by civil war, by the Great Rebellion. Hobbes' experience of the English civil war was what made a deep impression on his thought. He saw only two scenarios on the horizon: anarchy or authoritarian order. Anarchy corresponded to the homo homini lupus situation ${ }^{3}$ of continuous, permanent conflict that brings the greatest insecurity for goods and for the very life of each and every person. Security was for Hobbes the greatest good, and to ensure security a "Leviathan" State was needed, which had available all the means suitable to stifle conflicts. The social contract for Hobbes entailed the subjects' relinquishment of their freedom in exchange for security. Hobbes went so far as to assert that subjects are "servants" of the sovereign. For Hobbes too, then, politics consists essentially in suppressing conflict.

The same holds for the thought of Carl Schmitt, for whom politics was in the final analysis Machtpolitik, the politics of power, which required at the centre of the state an authority endowed with the power to make decisions, above rules and above the very Constitution. The state of exception, and thus an authority empowered with the force necessary to re-establish order and the security of the state should it be in danger, and then to preserve it. According to Schmitt the role of the state is to suppress conflicts and thus "domestic" politics is nothing other - in a situation of crushing conflicts than "administration". In this regard, no one should overlook that Schmitt actually wrote that Hobbes' Leviathan had its historical fulfilment in the Prussian "police" state. ${ }^{4}$

If this is the task of the state on its own soil, "real" politics is exercised abroad in the state's relations with other states. "Real" politics in other words is international politics. The universe, wrote Schmitt, is a multiverse, consisting of a plurality of political units/states. Relations of permanent conflict come to be established among states where the amicus/hostis, friendship/hostility, dichotomy predominates. Politics is a battle, an existential duel. One must here bear in mind that Carl Schmitt stands within the German tradition, where politics is predominately Weltpolitik. The great theoretician of this concept was Georg Wilhelm Friedrich Hegel, but another supporter of this idea was Heinrich von Treitschke (1834-1896), the other great German thinker, and yet another was Friedrich Ratzel (1844-1904). The underlying idea of this "German ideology" was that Germany should dominate

3 "A man is a wolf to another man."

4 See Carl Schmitt The Leviathan in the State Theory of Thomas Hobbes: Meaning and Failure of a Political Symbol (George Schwab and Erna Hilfstein (translators), University of Chicago Press, Chicago, 2008). See also Schmitt's essays listed in the article by Martin Jänicke "Die 'Abgründige Wissenschaft' vom Leviatan: Zur Hobbes-Deutung Carl Schmitt sim Dritten Reich" (1969) 16 Zeitschrift für Politik 401 at 401, n 2. 
international politics and be the supreme overseer of the international community: Deutschland überalles. This ideology - 1,000 light years' distant from the "pacifist" teaching of Immanuel Kant would lead ultimately to the tragedy of World War II and to catastrophe for Germany.

\section{$B$ The Regulation of Conflict View}

Other thinkers conceived politics as the regulation of conflict. This means the ritualisation of conflict by way of rules is able to channel it towards a peaceful, non-violent solution. They deem conflict to be physiological, thus the existence of rules and mechanisms suitable to ensuring compliance serves to reduce conflicts.

Kant, in particular, discussed the natural "unsocial sociability" of human beings. This "unsocial sociability" indicated continuous, permanent competition among human beings. Kant added that this "unsocial sociability" is beneficial inasmuch as competition favours innovations of sundry nature, leading - if one wants - to the free market as the place of competition; and competition, to really be competition, is ritualised conflict. Thus for Kant, conflict should not be suppressed or stifled, rather it should be regulated by general norms, that is on the basis of the principle that each individual's rights end where another individual's start. The constitution of society for Kant is that which "institutionalises" conflict, ritualises it through certain essential regulations. The experiment started by the Founding Fathers of the United States from 1776 to 1789 was precisely that of ratifying a Constitution able to pacify conflict, ritualising conflict so as to favour and protect the independence of civil society understood as the core of multiple freedoms, in particular freedom of religion, of speech and of trade.

Without doubt Hans Kelsen belongs to this line of thought. Kelsen is under no illusion that, even far in the future, a human brotherhood with no conflicts might be achieved, while on the other hand he vehemently rejects an authoritarian concept of politics. Kelsen's critique of both Schmitt's view and the Communist, eschatological, view of politics, is that both maintain a fundamental premise. Kelsen's own view starts from the idea that conflicts are physiological and normal within every society and among states. Underpinning his entire reasoning is his assumption of the pluralistic model, that is, of a peaceful plurality of subjects (trade unions, political parties, economically powerful groups and so on) operating within a common political arena where subjects interrelate in a situation of permanent conflict.

For Schmitt, if there is conflict there is no cooperation, and conversely if there is cooperation there is no conflict: these two elements cancel each other out. The "liberal" Kelsen on the contrary imagines the possible co-existence of cooperation and conflict; although the two exist in permanent tension, they are not incompatible. Without cooperation society would be impossible. On the other hand stifling conflict entails an authoritarian system, leading to the suppression of freedom. The constitutional state thus fulfils a precise and fundamental task, which is not to eliminate conflicts but merely to defuse them. The state must operate in such a way that conflicts are not violent or lacerating and that they do not take on the form of civil war. 
The idea of the constitutional court that we owe to Hans Kelsen, had the aim - on par with the American judicial review - of ensuring that the Constitution be deemed effectively "law" in its specific meaning: not only is the democratic system constitutionalised, but in this way it is also jurisdictionalised. The Constitution, as the highest law of the land, lays down the main rules of the game, which are also the endorsed rules for peaceful resolution of political and social conflicts. The judicial protection of the Constitution in its turn determines the transposition of political struggle onto the plane of legality and thus functions as pacification. Kelsen tried, after World War II, to apply his ideal of pacification at an international level as well. In those days - 1944-1945 - universal society, the whole human race, cried out loud and strong its irrevocable veto: "no more wars". That now faroff cry echoed the words of Kant against the war. ${ }^{5}$ The proposal Kelsen advanced at this point is the creation - based on international agreement - of a Court endowed with compulsory jurisdiction invoked to settle controversies between states. ${ }^{6}$ And after Kelsen, and based on his teachings, the European Economic Community (EEC) first, and the European Union later, have indicated the force of the law interpreted by a supranational court of justice to be the peaceful and sustainable alternative to the law of force in relations among European states. Kelsen proposed replacing the use of force with that of law as the means of achieving peace.

\section{Eschatological View of Politics}

Establishing itself over centuries in the Western world, above all resulting from the penetration of Jewish culture by means of Christianity into European civilisation, the eschatological view is the third "family" that conceives politics as the redemption of conflict. Whereas on the first view politics stifles conflict and on the second view it regulates conflict, here politics evaporates it, in this way creating what Karl Marx called a "harmonious society" in which power relations disappear and there are no more conflicts. According to Sternberger, the forefather of this eshcatological view of politics was Saint Augustine, who believed that the true role of politics was to produce a brotherly society where conflict could no longer even be conceived of. ${ }^{7}$ We have on this "view" anarchic society in the best sense of the word. In the City of God, like in the stateless and classless society envisaged in the social ideology of Marx and Friedrich Engels, conflict would vanish. Looking closely, the basic idea here is that it is necessary to extirpate conflict from the root. Let me explain: the authoritarian policy is to stifle conflict; it abolishes freedom of speech, of assembly and of political and trade union organisations. Regulatory politics in its turn aims to sterilise conflicts, defusing their explosive charge. Eschatological politics instead has as its final aim conflict-free society, and has been applied, in modern times, through the theory and practice of Bolshevism.

5 See Howard Williams Kant and the End of War: A Critique of Just War Theory (Palgrave Macmillan, London, 2012).

6 Hans Kelsen Peace Through Law (University of North Carolina Press, Chapel Hill, 1944).

7 Sternberger, above $\mathrm{n} 1$. 


\section{The (Various) Epistemological Bases of Politics}

The epistemological bases of these three forms of politics are also diverse. It is possible to classify epistemology, that is to say the theory of knowledge, in two broad groups: "absolutist" and "relativist". "Absolutist" epistemology represents an absolute truth, be it a sacred truth or a profane truth lived "as if" it were a sacred truth, a secular religion. This epistemology leads inevitably to authoritarian modalities of government. Affirming itself as absolute truth, religion whether sacred or profane seems in fact to contradict one by one all of the premises and all of the rules of democratic decision-making. The certainties of faith, once brought into the arena of politics, are by their very nature non-negotiable, and it is for precisely this reason that they present an insuperable incongruence with the essential and indispensable modalities of the democratic process: from the mutable judgement of the collective manifestations at elections and referenda to public debate, from the equal status granted to the various opinions voiced in political discourse to the need for compromise and from the principle of majority rule to the principle of free consent expressed by citizens.

In comparision, "relativist" epistemology, dismissing as it does transcendental arguments from political discourse, renders democracy manageable, all of which Kelsen understood before and better than anyone else. In Kelsen's thinking, in fact, the epistemological base of democracy - governance limited by the rule of law and operating within a society consisting of free and equal members, where pluralism is conjoined with tolerance - is relativist knowledge; and this, both on the scientific and ethical planes, is the only way to avow freedom and equality, that is, democracy. This is how Kelsen precedes Friedrich A Hayek and Karl Popper. The common battle fought on the field of epistemology and politics by both Popper ${ }^{8}$ and Hayek ${ }^{9}$ rests on the concept that, starting from the idea of absolute knowledge, the only possible conclusion is absolutism.

\section{KELSEN'S FIRST BOOK - DIE STAATSLEHRE DES DANTE ALIGHIERI.}

It is now time to expand upon some reflections on Kelsen towards the end of his university studies, published in 1905 and finally used by him as the text for his degree dissertation at the Law Faculty of the University of Vienna (1906). ${ }^{10}$ Die Staatslehredes Dante Alighieri was intended by young Kelsen

8 Karl Popper Conjectures and Refutations: The Growth of Scientific Knowledge (Routledge and Kegan Paul, Abingdon-on-Thames (UK), 1963).

9 Friedrich A Hayek The Fatal Conceit: The Errors of Socialism, (WW Bartley III (ed), Routledge, Abingdonon-Thames (UK), 1988).

10 Hans Kelsen Die Staatslehre des Dante Alighieri (Deuticke, Vienna, 1905) (translated ed: La teoria dello Stato in Dante (Boni, Bologna, 1974) and, more recently, Lo Stato in Dante (Mimesis Edizioni, MilanoUdine, 2017)). The page numbers of Die Staatslehre des Dante Alighieri mentioned below refer to the latest Italian edition. 
to be an analysis of De Monarchia by the poet Dante Alighieri elaborated from a viewpoint of law and state theory. ${ }^{11}$

Kelsen was proud of this book. He wrote in Autobiographie: "[i]t is in any case the only book of mine not to have been criticised adversely", adding that it "was well received also in Italy". ${ }^{12}$ Kelsen was referring to the review by Arrigo Solmi. ${ }^{13}$ Evidently Kelsen had only read the short introductory paragraph of Solmi's essay, in which Solmi wrote encouraging words on the book: ${ }^{14}$

In a learned volume, Kelsen, a German [sic] scholar [sic] has undertaken a systematic exposition and critical examination of Dante Alighieri's political doctrine, seen from a juridical viewpoint; and his undertaking warrants praise, because, even amidst an abundance of literature on Dante it is opportune that a scholar should trace, with systematic rigour, Dante's line of thought concerning the public law of the State. I will attempt to show in what way Kelsen has pursued his task, referring to his book, the fruit of diligent examination of Dante's works and of the literature dealing with this topic, and thus worthy of attention and study.

Kelsen evidently did not read further, to the critical note that was quite harsh and substantive: ${ }^{15}$

Here we find a shortcoming in this book, albeit praiseworthy in other respects. Kelsen, intending to draw in terms of political science a systematic outline of the Monarchy, does not take into account that this work focusses singularly on the doctrine of universal monarchy, that is, on the political form of the Empire, and not on the organisation of the State and its form.

And further: ${ }^{16}$

11 One of the best English editions of Dante's De Monarchia is The De Monarchia of Dante Alighieri (Aurelia Henry (ed and translator), The Riverside Press, Cambridge, 1904).

12 Hans Kelsen Autobiographie (1947) at 73. The passages in the text of my "reflections" and the page numbers mentioned therein, refer to the Italian edition: Hans Kelsen Scritti autobiografici (Mario G Losano (ed and translator), Diabasis, Reggio Emilia, 2008). Kelsen's Autobiographie of 1947, together with the (very much shorter) Selbstdarstellung of 1927, have remained unedited for many years, until in 2006 they were collected and published in a single small volume that was presented to the Austrian Parliament on the occasion of the 125th Anniversary of Kelsen's birth. Its translation from German into other languages followed.

13 Arrigo Solmi "Recensione a Hans Kelsen, Die Staatslehre des Dante Alighieri" (1907) 2 Bollettino della Società dantesca italiana at 98 , later re-published in Arrigo Solmi Il pensiero politico di Dante: studi storici (La Voce Edizioni, Firenze, 1922) at 127-155.

14 At 127.

15 At 132

16 At 133 
The defect of Kelsen's book lies thus in a misunderstanding that leads to a misinterpretation of Dante's work on many sides. The chapter on the Universal Empire, that Kelsen places at the end of his book, should have been the premise to his whole exposition of Dante's political doctrine.

Thus Solmi's criticism of Kelsen's Die Staatslehre was quite radical. The fact is that Solmi subjected Kelsen's essay to a philological and historiographical analysis to determine whether Kelsen had interpreted Dante's thought on the state correctly or not. This is, naturally, a perfectly legitimate approach of assessment, then as now, and moreover the only one possible, before Kelsen ... became Kelsen!

Solmi's criticism, apposite and correct from his point of view, nevertheless draws attention to the fact that Kelsen, in retracing Dante's thought on the state, "recreates" it in the image and likeness of certain ideas on law and state that were evidently already present in some way in his own mind. This is to say that there is another analytic approach that we can today pursue more profitably: we can, that is, ascertain whether in his first book, it is possible to discern some fragment, some bud, of the ideas about law and the state that characterised the "mature" Kelsen.

First of all let me here pose a question: why did Kelsen choose Dante's De Monarchia as the subject of his first research destined for publication? This is a question Kelsen himself was at pains to answer, and in a way that I would say was trivially autobiographical: it was because, wrote Kelsen in his Autobiographie in 1947: ${ }^{17}$

In the literature on Dante I had not found any monograph treating the poet's doctrine on the State; and furthermore I said to myself that it would be better to engage in work that interested me rather than losing any enthusiasm for study of the law and of the State, limiting myself to studying only to pass exams.

However the "intellectual" and so to say ideological answer may be another. In fact exactly 37 years later, in 1944, Kelsen wrote - when World War II was not yet over! - Peace Through Law, where he describes the way in which it would be possible to construct a federal world state destined, in his view, to ensure perpetual peace among world nations. And it may not be by chance that Kelsen emphasises, quoting from Die Staatslehre, ${ }^{18}$ certain passages where Dante - in De Monarchia I, 7 and in Convivio IV, 4, concludes that it is precisely the need for peace that leads sundry kingdoms to the institution of a universal empire: how, at the beginning, one step at a time, man, by nature a "social animal" required a "family", and soon later "a city" and then, always "for the fulfilment of peace and happiness", "monarchy", so for the same reason in the future the world state will be born. I would add in passing, that in delineating the futurable formation of a world state Kelsen pointed out certain essential criteria: gradualism, sectorialism, that is the "line of least possible resistance," the centrality of an International Court of Justice with recognised compulsory jurisdiction concerning litigation among states, whether

17 Kelsen Autobiographie, above n 12, at 73.

18 Kelsen Die Staatslehre des Dante Alighieri, above n 10, at 90-91. 
"political" or "legal" and finally the supranational nature that should characterise the way the judges of that Court should exercise their mandate. Precisely those same criteria would come to form the basis of first the European Coal and Steel Community (1951) and subsequently the EEC (1957), that has now become by subsequent evolution the EU. ${ }^{19}$

Regarding the contents of Die Staatslehre, it must be admitted that there were already present in Kelsen's thought - albeit certainly not yet at an entirely conscious level -some of the ideological and cultural co-ordinates related to law and the state, in terms of which the thought of that great scholar of law would gradually develop, as if following an already established course. These co-ordinates, already present in Kelsen's mind in Die Staatslehre, are: peace, limited government and democracy. Thus Kelsen already was, and after a brief period when he had been seduced by "the materialistic concept, which I came to know, as was then usual, through Buchner's Kraft und Stoff", ${ }^{20}$ a pacifist, a liberal and a democrat.

Above all (but not exclusively) in the "dogmatic" chapters, as they were once known, that is in the chapters specifically devoted to Dante's state doctrine, studied from the legal point of view, there resurface - emphasised in Dante's thought, or attributed to Dante - some of the anchors of what would, starting from Hautprobleme der Staatsrechtslehre, ${ }^{21}$ be Kelsen's "scientific theory of law" and of the state, the first being the identification between state and law. The state, for Kelsen, is none other, from the strictly legal point of view, than a whole set of norms, offices, competences, procedures, of rights and obligations. This is a point that he attributes to Dante, that Kelsen repeats over and over again: "[h]e [Dante] recognises the deep ties, the inseparability of both concepts - law and State - and also makes a statement in this regard" 22 when he asserts that the state is a constitutional state in the sense that "the exercise of power appears bound by law", ${ }^{23}$ and when he reiterates several times that for Dante the idea of the state qua constitutional state is such as to strip "this position (of the sovereign) of any potentially despotic character". ${ }^{24}$ The identification of state and law is moreover reiterated when Kelsen discusses sovereignty as an "office" that certainly confers authority but to the same extent imposes obligations; as a "service" to carry out on behalf of the whole collective; as an "organ" of the state. Kelsen, furthermore, stretching matters somewhat, discovers an ambiguous passage of Dante's, De Monarchia III, 7, which says "auctoritas principalis non est principis nisi ad usum...",25

19 I have traced in detail this "singular" analogy in "Hans Kelsen: A PeacemakerThrough Law" (2014) 45 VUWLR 647.

20 Kelsen Autobiographie, above n 12, at 69.

21 Hans Kelsen Hautprobleme der Staatsrechtslehre (1911).

22 Solmi Il pensiero politico di Dante, above n 13, at 127-128.

23 At 130

24 At 126

25 At 126 
the idea "that reduces the position of the monarch in the state to a handover not of law but rather of the exercise of state power, and advocates the principle: populous maior principe". ${ }^{26}$ Whoever governs in the name of the people - the sovereign - does so within the limits of the law: Thus in Kelsen's thought, liberalism and democracy already went hand in hand in Die Staatslehre.

Closely tied to the relation between law and state - the identification between state and law - is the problem of obedience to the law. Already in Die Staatslehre Kelsen underlines the subjects' obligation of obedience to the law as a value. Indicative in this regard is a phrase that Kelsen quotes in the text: "[i]n the subject's obedience to the commands of the state, to laws, Dante sees not slavery or servitude, but instead supreme freedom". ${ }^{27}$ This phrase warrants comment. Kelsen wrote the justcited phrase in relation to a passage inserted in Dante's Lettera ai Fiorentini of 1311. Dante, commented Kelsen, did emphasise the obligation to obey laws, but he does so in the context of the ${ }^{28}$

\footnotetext{
... rigorously republican constitution of Florence ... The extremely democratic politics of Dante's native

city had precisely generated a conception of the state far clearer and more pronounced than generally the

Medieval period had been mature enough to produce.
}

Nevertheless there is no doubt that Kelsen had always underlined the compulsory character of obedience to the law as it is and inasmuch as it is so. This is a delicate point that has given rise to the most grave misunderstandings. Ernst Cassirer, writing in 1932 - a critical year for the Weimar Republic - his work titled Vom Wesen und Werden des Naturrecht, labels Kelsen an apologist of "empty" law, that is of a theory that served to weaken the defences of democracy in Germany and thus favoured the enemies of the Weimar Republic (and which then, according to others, helped the Nazis hold on firmly to the reins of power). Hidden here lies an enormous misunderstanding. When he detaches law from justice and affirms that "law" can also be deemed "law" in its own rights when it is "unjust", Kelsen dismisses the allegation that by obeying the law one obeys justice. Certainly obeying the law - whether just or unjust - is for Kelsen a duty from the legal point of view, as long as the national law is valid and in force and thus effectively binding. But, alongside the legal duty of obedience to the law there are other duties, other values: not legal but religious or more generically ethical, present within the conscience of each of us. These duties may conflict, also radically, with the obligation, which nevertheless subsists, to obey the law. In such a case the individual must choose between incompatible obligations. If they choose obedience to the law they will have trouble with their conscience, and at times the costs can be very high; should obedience to their own idea of what is just prevail they will have to pay the relative penalty imposed by law. The plain truth is that obedience to the Nazi regime or to that of Pol Pot or any other atrocious regime has nothing, absolutely nothing, to do with legal positivism; it had rather to do with the general consensus, established in

26 Kelsen Die Staatslehre des Dante Alighieri, above n 10, at 127.

27 At 105

28 At 106 
those countries where such regimes took power, that they were ideologically "just" and therefore to be supported.

So far, this is what the student Hans Kelsen said, or had Dante said, before he became Hans Kelsen. However other issues characteristic of Pure Theory of Law remain in his analysis of monarchy - if not unspoken, quiet. To be precise, I am referring to the monism in the relations between international law and the domestic law of states, that Kelsen declares he adduced from a text written in 1914 by his student Alfred Verdross; and to the basic norm or Grundnorm posited by Kelsen at the top of the hierarchical structure of the legal system - the Stufenbau. Kelsen attributed the conception of the basic norm (and of the Stufenbau) to his other major disciple, Adolf Julius Merkl. And finally I refer to the constitutional court, Kelsen's great "invention": "[t]he first of this type in the history of constitutional law", wrote Kelsen in Autobiographie, adding: "[u]ntil then no tribunal had had the competency to repeal laws due to unconstitutionality with general application, that is, not limited to single cases". 29

But, but...

\section{A Monism}

I have spoken of Kelsen's natural disposition towards a world state that seems already discernible in his analysis of Dante's universal Empire. Now, the contour of a world state of federal type, such as the one Kelsen was to delineate many years after having written his first book, is in the end none other than the frame of a unitary relation between federal law and the law of the member states of the federation; that is, none other than applied monism.

\section{B Basic Norm}

In Die Staatslehre, Kelsen on at least two occasions broaches the subject of "basic norm". Concerning the passage of power implemented by Pope Adrian I in favour of Charlemagne, Kelsen wrote that Dante: ${ }^{30}$

... resolutely refutes the opinion generally held since the time of Pope Innocent III, that Pope Adrian took the imperial dignity from the Byzantine Empire and handed it over to Charlemagne in recognition of the latter's help against the hostile Lombards,

adding that Dante "deemed the pope not authorised to grant such an assignment; such would entail not the law but only usurpation of the law", concluding that "Dante does not see a positive solution to the question" 31 of the legal basis of such a transfer of power. Neither is a solution given by the student Kelsen, obviously, who nevertheless is very clear in his own mind about the problem. It would be

29 Kelsen Autobiographie, above n 12, at 109.

30 Kelsen Die Staatslehre des Dante Alighieri, above n 10, at 161.

31 At 161. 
resolved, mediated by Adolf Merkl, by the "mature" Kelsen through the discovery of the Grundnorm which, in my opinion, is none other than - as the highest authority reached by deference proceeding upwards step by step - convictions held in general by the law-abiding collective concerning the legitimacy of power and who is exercising it. ${ }^{32}$

\section{Constitutional Tribunal}

Kelsen at the time of the De Monarchia posing almost in passing while discussing the limit constituted by law to the exercise of state power by the sovereign, a question that shortly afterwards would assume for him exceptional importance. Kelsen asks himself, "what would be the consequences of a transgression of the binding juridical limits to both state power and to the position of the sovereign?"33 and observes in this regard that "little is found on this point in Dante, almost nothing". ${ }^{34}$ The answer that a little over 10 years later Kelsen, now "mature", would give to the problem of how to ascertain and sanction eventual transgressions of limits set by the Constitution to the power of the modern "sovereign" - the elected Parliament - would be the creation of the constitutional court as the judge of legislative acts.

32 I refer readers to my article about Hans Kelsen: see Patrono, above n 19, at 653.

33 Kelsen Die Staatslehre des Dante Alighieri, above n 10, at 132.

34 At 132 . 
